\title{
Correction to: Weighted gene coexpression network analysis-based identification of key modules and hub genes associated with drought sensitivity in rice
}

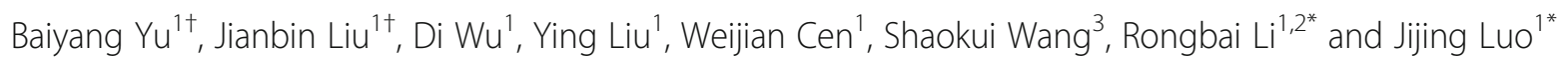

\section{Correction: BMC Plant Biol (2020) 20:478} https://doi.org/10.1186/s12870-020-02705-9

Correction

In the original publication of this article [1] the author would like to correct the author affiliation sequence and affiliation of Rongbai Li and Jijing Luo. In this correction article the author and the corresponding details are provided.

Baiyang $\mathrm{Yu}^{1+}$, Jianbin $\mathrm{Liu}^{1+}, \mathrm{Di} \mathrm{Wu}^{1}$, Ying $\mathrm{Liu}^{1}$, Weijian Cen ${ }^{1}$, Shaokui Wang ${ }^{3}$, Rongbai $\mathrm{Li}^{1,2^{*}}$ and Jijing Luo $^{1 *}$

1. College of Life Science and Technology (State Key Laboratory for Conservation and Utilization of Subtropical Agro-bioresources), Guangxi University, Nanning 530004, China

2. Agriculture College, Guangxi University, Nanning 530004, China

3. Agriculture College, South China Agricultural University, Guangzhou 510642, China

The original publication has been corrected.

\section{Author details}

${ }^{1}$ College of Life Science and Technology (State Key Laboratory for Conservation and Utilization of Subtropical Agro-bioresources), Guangxi University, Nanning 530004, China. ${ }^{2}$ Agriculture College, Guangxi University, Nanning 530004, China. ${ }^{3}$ Agriculture College, South China Agricultural University, Guangzhou 510642, China.

The original article can be found online at https://doi.org/10.1186/s12870 020-02705-9.

*Correspondence: lirongbai@126.com; jjluo@gxu.edu.cn

${ }^{+}$Baiyang Yu and Jianbin Liu contributed equally to this work.

'College of Life Science and Technology (State Key Laboratory for

Conservation and Utilization of Subtropical Agro-bioresources), Guangxi University, Nanning 530004, China

Full list of author information is available at the end of the article
Published online: 10 November 2020

\section{Reference}

1. Yu B, et al. Weighted gene coexpression network analysis-based identification of key modules and hub genes associated with drought sensitivity in rice. BMC Plant Biol. 2020;20:478.

(c) The Author(s). 2020 Open Access This article is licensed under a Creative Commons Attribution 4.0 International License, which permits use, sharing, adaptation, distribution and reproduction in any medium or format, as long as you give appropriate credit to the original author(s) and the source, provide a link to the Creative Commons licence, and indicate if changes were made. The images or other third party material in this article are included in the article's Creative Commons licence, unless indicated otherwise in a credit line to the material. If material is not included in the article's Creative Commons licence and your intended use is not permitted by statutory regulation or exceeds the permitted use, you will need to obtain permission directly from the copyright holder. To view a copy of this licence, visit http://creativecommons.org/licenses/by/4.0/ The Creative Commons Public Domain Dedication waiver (http://creativecommons.org/publicdomain/zero/1.0/) applies to the data made available in this article, unless otherwise stated in a credit line to the data. 